\title{
ETIK DAN EMIK PADA KARYA ETNOGRAFI
}

\author{
M. Rawa El Amady ${ }^{1}$
}

\begin{abstract}
Important lesson of the two in the ethnographic work even when doing ethnographic research, ethics and emic is not a separate thing. Both are an integral part in the research process as well as in his writing. So, in an ethnographic work could not leave ethics, or leave emic, but they must appear in accordance with periodesasinya respectively.
\end{abstract}

Key words: Ethics, Emic, Etnography, Research

\section{A. Pendahuluan}

$\mathrm{T}$ ulisan yang saya sajikan ini mencoba mengembangkan diskusi etik dan emik menjadi lebih fokus dan spesifik terutama pada karya etnografi. Saya tidak ingin terjebak dalam suatu persepsi perbedaan konsepsional antara emik dan etik, tetapi saya ingin melihat posisi etik dan emik pada karya etnografi yang belum dibahas oleh keduanya. Selama ini pembahasan tentang etik dan emik masih terbatas pada level teknikal pengambilan data. Padahal ilmu antropologi sejak tahun 1980-an berkembang begitu cepat, begitu juga etik dan emik ikut berkembang sehingga tidak hanya terbatas pada masalah teknikal pengambilan data, dan hubungan etik dengan masing-masing paradigama. Etik dan emik sudah melekat dan saling mempengaruhi paradigma.

Menurut saya berkaitan dengan etik dan emik dalam kajian etnografi ada beberapa isu penting yang perlu diperdalam, yaitu pertama, posisi penulis. Posisi dalam arti bagaimana penulis memperlakukan konsepsi Pike dan Harris, pada bagian definisi yang dipakai Pike tetapi pada bagian pembahasan dipakai Harris, yang tentu saja menyebabkan kekacauan karena Harris dan Pike berada pada stand point yang berbeda. Kedua, belum ada penjelasan yang tegas keterkaitan antara paradigma dalam antropologi dengan isu emik dan etik tersebut. Saya belum menemukan justifikasi bahwa terdapat perbedaan perlakuan antara emik dan etik pada masing-masing paradigma. Ketiga, konsep etik dan emik belum bisa operasional untuk menilai karya etnografi, dataran emik dan etik masih pada perdebatan epistiomologi. Oleh sebab itu, agak kesulitan untuk memulai suatu kerja akademik atas penilaian sebuah karya etnografi pada perspektif etik dan emiknya. Ini dapat dipahami karena karya-karya yang membahas etik dan emik memang masih saja menonjolkan perdebatan antara Harris dan Pike

Dari ketiga tema yang perlu diperdalam tersebut, saya mengambil tema etik emik pada karya etnografi, melalui tema ini saya bisa memahami hubungan emik dan etik dengan paradigma dan akan mencoba mengoperasionalkan perspektif etik dan emik pada karya etnografi. Ini saya lakukan karena tujuan utama dari artikel saya adalah untuk mengoperasionalkan konsepsi emik dan etik pada karya etnografi.

\section{B. Tujuan Kajian}

- ecara akademis tujuan penulisan artikel ini adalah untuk pertama, memahami perspektif etik dan emik pada karya etnografi. Diharapkan melalui artikel ini pembaca karya etnografi bisa memahami perspektif emik dan etik pada karya yang dibacanya. Kedua, memahami

\footnotetext{
${ }^{1}$ Penulis adalah Direktur PADI Institute, Jakarta (rawa@lycos.com, www.mrawaelamady.com)
} 
posisi etik dan emik dengan paradigma antropologi. Melalui artikel ini akan terlihat dengan jelas pada paradigma mana etik dominan dan atau emik dominan. Ketiga, tentu saja setiap karya ilmiah diharapkan mampu memberi kontribusi bagi pekembangan kajian etik dan emik studi etnografi.

\section{Perdebatan Pike dan Harris}

U ntuk membahas ini saya bersentuhan dengan Headland (1990) sebagai acuan utama dan artikel lain yang relevan. Mengapa perdebatan ini saya anggap penting. Karena sebenarnya menurut saya isu etik dan emik yang muncul mulai dari tahun 1960-an sampai tahun 1980-an masih berkisar perdebatan konsepsional tentang etik dan emik yang dimotori Harris dan Pike. Meminjam istilah Bernstein yang menyebut perdebatan Pike dan Harris sebagai "dialogue approach".

Menurut saya fokus perdebatan Pike dan Harris apa yang disebut James Lett (1990) terletak pada epistimologi dari antropologi. Perdebatannya lebih kepada asal muasal dari etik-emik dalam antropologi. Pike dan Harris berada pada posisi yang sangat berbeda, baik dari disiplin ilmu maupun paradigma. Headland menyebut hal ini dengan stand point yang berbeda. Pike dinilai Headland seorang idealis yang berlatar belakang linguistik mengembangkan teori Tagmemics, sedangkan Harris seorang antropolog naturalis dengan teori Cultural Materialism. Oleh sebab itu, Pike dan Harris tidak menggunakan etik dan emik pada satu jalan, aplikasi dan definisi yang mereka pakai berbeda. Hal ini menurut Lett sebagai perbedaan asumsi dasar yang mengarisbawahi teori mereka.

Persoalan epistimologi dan stand point ini mempertajam perlakuan etik dan emik dalam karya ilmiah. Pike, pada penelitian sosialnya memperlakukan etik dan emik sebagai satu kesatuan dari unit analisis. Sedangkan Harris memperlakukan etik sebagai cara bagi etnografer untuk mendapatkan informasi dari masyarakat, dimana informasi dari masyarakat tersebut sebagai emik. Harris memposisikan etik dan emik sebagai suatu strategi penelitian, sedangkan Pike bukan pada strategi penelitian tetapi konsep yang utuh. Emik melibatkan suatu sistem mental dan fisikal yang relevan dengan prilaku mereka, meliputi unit persepsi prilaku pengguna asli, merupakan karateristik dari perbandingan, keterlibatan budaya asli, pembedaan, relevan dengan tempat, hirarki dan pola kebudayaan terbentuk, dan tujuan dari individu dalam bermasyarakat. Pike sangat lingusitik.

Sementara itu, Harris melihat emik dan etik dari pandangan antropologi yang lebih bersifat natural berdasarkan kultural materialisme sebagai suatu bagian utuh untuk menghasilkan karya etnografi. Label emik dan etik penting untuk memahami beberapa item seperti konsep, aksi, kepercayaan, aturan, dan berbagai hal. Sebab itu, Harris melihat Etik sebagai pandangan orang luar, sedang emik pandangan orang dalam. Etik dan emik akan berhubungan dengan masalah objektif dan subjektif. Etik bersifat sangat tertutup dalam hal makna, seperti prinsip objektif. Tetapi emik tidak bisa disejajarkan dengan subjektif saja tetapi bisa juga disejajarkan dengan objektif dan subjektif sekaligus

Bagi Harris, emik digunakan untuk studi sosial kultural yang berdasarkan penomena, dengan membanguan konsepi diakronik, sinkronik, koparatif, global sains dan kultur. Emik penting dalam penelitian untuk menghilangkan kepentingan dan motivasi peneliti dari luar dan menghapus salah keterwakilan dalam tradisi ilmuan tradisional. Atas alasan inilah maka emik peneliti harus dikategorikan berbeda dengan emik dari masyarakat yang ditelitinya. Atas dasar pertimbangan ini maka kita memerlukan istilah etik sama baiknya dengan emik.

Harris (1976) melihat emik merupakan sesuatu yang ada dalam pikiran inside people sedangkan etik cara bagaimana mengetahui apa yang ada dalam pikiran inside people tersebut. Emik merupakan pengungkapkan suatu yang aktual akan konteks interaktif potensial dalam perjumpaan enografer dengan informan dan melakukan dikusi sesuatu yang dominan. Sedangakn etik merupakan status nonesenisal logika dari pelaku peneliti sebagai orang luar. Jadi etik mengacu kepada pesan yang ada di dalam aturan yang dibuat untuk memperoleh emik, sementara emik sendiri berada di 
dalam pemikiran kepala aktor. Emik dan etik terletak pada prilaku komunikasi dan untuk mengetahui arti pengungkapan, pidato dan komunikasi harus berdasarkan prilaku emik. Menurtu Harris lagi, semua yang keluar dari pemikiran orang dalam disebut emik. Selain itu, Harris mengemukakan juga bahwa peneliti memiliki etik dan emik, etik peneliti jika terdapat jarak yang jauh dan penilaian dengan partisannya, sementara peneliti menjadi emik ketika jarak dan penilain tidak ada dan dipengarui oleh nilai sendiri.

\section{Posisi Penulis}

U ntuk membahas tema ini sebagaimana yang saya pikirkan, maka saya akan menjelaskan posisi saya melihat posisi etik dan emik selalu ada dalam semua karya etnografi. Seorang peneliti tidak bisa melepaskan dari dari persentuhan dengan etik walaupun peneliti sudah menggunakan paradigma postmoderenisme sekalipun. Begitu juga, peneliti tidak bisa lagi terlepas persentuhan dengan emik karena tuntutan perkembangan ilmu sosial yang sedemikian rupa.

Sebenarnya semua etnografi dimulai dari etik. Keputusan untuk menentukan subjek penelitian merupakan pilihan etik etnografer memilih subjek tersebut. Pilihan ini secara langsung atau tidak langsung mempengaruhi etnografer dalam menyusun rencana terhadap subjek penelitian yang dipengaruhi oleh sudut pandang kita dalam memilih subjek yang kita minati. Begitu pula, pada bagian penentukan tema-tema judul dan bab, walaupun datanya diperoleh secara emik tetapi tetap saja sudut pandang teori ikut terlibat didalamnya. Seorang peneliti etik setidaknya akan menggunakan pendekatan emik pada teknik pengambilan datanya.

Saya memahami etik dan emik sebagai suatu bagian paradigmatik yang menjadi subtansi kognitif peneliti dalam memproduksi karya antropologi dan etnografi. Subtansi kognitif tersebut tercermin dengan jelas dari pilihan paradigma dan perangkat teoritis yang menyertainya. Bagaimana peneliti memperlakukan teori, memperlakukan informan, menvalidasi data dan mengkonstruksi data. Karya seperti
Malinowski, (1922) tentang pulau Trobian dan karya Ana Tsing (1998) Dibawah Bayangan Ratu Intan adalah dua karya yang teknik pengambilan datanya sama tetapi dalam perlakuan terhadap suara informannya sangat berbeda. Perbedaan tersebut disebabkan kognesi paradigmatik penelitinya yang berbeda.

Oleh sebab itu, saya tidak ingin terlibat dalam perdebatan teoritis tentang etik dan emik, perbedaan keduanya, serta perlakuan atas keduanya. Saya ingin secara langsung membahas setidaknya lima karya etnografi berbeda. Melalui pemahaman mendalam bagaimana etnografer memperlakukan etik dan emik pada karya etnografinya. Ini saya lakukan karena bagi saya akan lebih mudah untuk memahami isu etik dan emik pada penelitian antroplogi dan etnografi yang akan saya lakukan.

Bagaimana saya membaca etik dan emik dalam karya etnografi? Pertama, etik dalam pemahaman saya terdiri dari etik peneliti dan etik informan. Etika peneliti adalah perangkap teoritis yang menjadi acuan peneliti, perangkap teoritis tersebut meliputi bagaimana peneliti memperlakukan dirinya terhadap perangkap teoritis tersebut, dan bagaimana perangkap teoritis tersebut menjelma menjadi teknik pemilihan informan, pemilihan data, dan penentuan ide-ide dalam tulisan. Harris (1976) secara jelas mengungkap bahwa etik merujuk kepada kerangka teoritis bagi observer untuk mendapatkan emik. Kalau kita membaca The Religion of Java karya Geertz dengan mudah tergambar bahwa abangan, santri dan priayi diproduksi secara etik oleh penelitinya, sebelum mengambil data peneliti pasti sudah punya asumsi yang memandunya ke situ. Padahal teknik pengambalin datanya menggunakan pendekatan emik bahkan lebih dari setahun tinggal bersama masyarakat.

Sedangkan etik informan adalah pemikiran informan yang merupakan bayangan ideal yang diingin oleh informan dan bukan merupakan gambaran yang merefleksikan empirik yang ada di masyarakat. Ini bisa terjadi misalnya satu orang terus menerus menjadi informan untuk beberapa penelitian yang sama ataupun berbeda. Maka informan tersebut 
mengungkapkan lebih daripada data empirik di masyarakat tersebut secara komunitas, tetapi mengungkan sesuatu yang ideal yang menurutnya baik dan tentu saja belum merupakan fenomena empirak komunitas tersebut. Kedua, emik bagi saya dipahami sebagai emik dari informan dan emik dari peneliti. Emik dari informan adalah adalah sebagaimana yang dikemukan Harris (1976) semua data yang diperoleh dari orang dalam, dalam tulisan karya etnografi akan terlihat bagaimana peneliti memperlakukan informan sebagai bagian utama dalam memproduksi karya etnografinya. Karya Ana Tsing (1998) Dibawah Bayang-bayang Ratu Intan, tampak sangat jelas bagaimana Tsing memperlakukan suara informan dalam karya etnografinya. Walaupun demikian, tema-tema yang muncul dalam tulisan tersebut tidak terlepas dari emik peneliti dan etik karena persentuhan dengan teoriteori.

Emik dari peneliti adalah daya nalar peneliti menginterpretasikan perangkap teoritis tersebut agar lebih empirikal dan menghasilkan interpretasi data emperikal yang tidak terjebak dalam pengujian teori. Termasuk juga didalamnya nilai-nilai sosial dan moral dan agama yang dimiliki peneliti. Jadi lebih kepada apa yang ada di kepala peneliti tanpa di pandu suatu kerangka acuan teori.

Mengapa saya memahami etik dan emik seperti ini. Ini saya lakukan agar saya tidak terjebak memahami etik dan emik secara linguistik sebagaimana awal konsep ini muncul. Etik dan emik pada konstruksi awal tentulah suatu konstruksi yang kaku hanya terbatas pada teknik pengungkapan bagaimana suara itu muncul. Sementara perkembangan antropologi sekarang ini telah membawa isu etik dan emik ke ranah yang lebih dalam, memasuki arena paradigma dan kognesi penelitinya.

\section{E. Pendekatan Penulisan}

ntuk memproduksi tulisan ini, beberapa langka yang akan saya lakukan. Starting point saya dari perdebatan teoritis sebagaimana dikembangkan pada dua karya terdahulu. Ini berarti saya tidak lagi mengulangi konsepsi-konsepsi teoritis yang sudah dibahas tersebut, saya akan memperdalam perdebatan tersebut dengan cara pandang saya melihat isu etik dan emik.

Bagaimana saya mendalami perdebatan tersebut? Pertama, saya akan ambil garis besar perdebatannya, setelah diperoleh garis besar perdebatan tersebut saya coba perbandingkan pada karya etnografi yang saya pilih. Kedua, saya memilih lima karya etnografi sebagai karya yang akan saya bahas berdasarkan garis besar yang diperoleh dari perdebatan teoritis tentang isu etik dan emik. Lalu karya tersebut saya katagorisasi berdasarkan konsepsi saya tentang etik dan emik sebagaimana yang saya utarakan pada bagian posisi penulis diatas. Ketiga, meskipun pada bagian awal saya sudah menentukan posisi saya terhadap isu etik dan emik ini dan bagaimana saya memahaminya. Saya tetap ingin ikut berdikusi tentang isu ini dan mempertegas bagaimana saya menterjemahkan isu etik dan emik ini dalam karya etnografi saya kelak.

\section{F. Metode Analisis}

D agaimana teknik untuk menganalisis Suatu karya ilmiah berdasarkan perspektif etik dan emik? Morris, Leung, Ames, dan Lickel, (1999) sangat membantu untuk memahami teks karya etnografi dari perspektif emik dan etik, meskipun tulisan tersebut bukan untuk mengalisis karya etnografi tetapi studi tentang pengaturan organisasi. Menurut Morris, untuk melihat suatu karya emik bacalah karya Malnowski tentang kepulauan Trobian dan karya interpretif Geertz. Penunjukkan dua karya tersebut terkesan Morris ingin menyampaikan bahwa partisipan observer model Malinowski sebagai karya emik yang penting dalam etnografi. Begitu juga penunjukkan interpretif Geertz juga terkesan bahwa paradigma interpretif mewakili kepentingan emik dalam etnografi.

Morris juga mengingatkan bahwa etik dan emik dalam suatu penelitian tidak bisa dibahas terpisah, keduanya merupakan suatu rangkaian yang saling melengkapi. Suatu karya tidak bisa dikatakan hanya karya etik saja, atau karya emik saja. Pada satu proses penelitian dan hasil karya penelitian selalu terdapat aspek etik 
dengan mudah menentukan stand point dalam melakukan anilisis etik dan emik pada karya etnografi.

Langkah ketiga, adalah mengenali historis keilmuan penulisnya. Historis keilmuan penulis itu penting sekali karena akan membatu memahmi paradigma yang lekat pada penulis tersebut. Walaupun paradigma tersebut bisa dibaca dengan jelas tanpa harus tahu historis keilmuan penulisnya, tetapi dengan mengetahui historis keilmuan penulisnya, akan mempermudah memahami paradigma dari tulisan yang dibahas. Morris, dkk dengan tegas mengungkap bahwa paradigma interpretif dan posmoderisme sangat dominan emik. Padahal Malinowskilah sebagai tokoh pertama yang menerapkan perinsip-perinsip emik pada penelitiannya walaupun dia strukturalis.

Langkah keempat, memilih pendekatan untuk membahas teks tersebut. Tadinya saya berfikir pedekatan konten analisis lebih tepat. Tapi saya tidak ingin menggunakan itu karena tantangan untuk menggunakan pendekatan hermeneutika terhadap satu teks lebih menarik minat saya. Pendekatan hermeneutika selalunya dipakai untuk menganalisis simbol pada etnografi interpretif simbolik (Holstein, \& Gubrium, 2005). Acep Iwan Saidi (2008) melakukan cara ini pada studinya tentang teks senirupa. Menurut saya teks karya etnografi tidak berbeda dengan teks karya seni rupa, bahkan teks etnografi lebih mudah karena teks tersebut menggunakan bahasa tertulis dimana semua makna bisa dipahami langsung. Sedangkan teks seni rupa, tidak langsung bisa bicara tetapi dipahami melalui analisis simbol.

Agar lebih jelas teknik analisisnya maka saya harus memperlakukan karya tersebut sebagai objek dan sekaligus subjek sebagai pusat yang otonom (Saidi, 2008) dengan demikian dialog antara teks dengan penafsir terjadi berulang-ulang dan tidak dibatasi oleh frame work paradigma tertentu. Agar dialog lebih tajam untuk memahami karya etnografi, maka kembali lagi kita berdialog dengan teks pesan apa yang disampaikan. Jika teks

terpengaruh Harris karena membedakan secara tegas antara etik dan emik, dan kedunya dipandang sebagai strategi penelitian. tersebut menyampaikan pesan penulis secara kuat karena keinginan menguji hipotesis atas teori tertentu dan ke field reseach dalam waktu terbatas dan menggunakan pengukuran dan perbandingan dengan budaya lain maka pesan positivisme sangat kuat. Ini berarti karya tersebut dominan etik. Begitu juga sebaliknya, jika pesan yang disampaikan tidak bermaksud menguji teori tertentu, observasi yang lama dan informannya secara otonom mengkonstruksi data, ini berarti karya tersebut dominan emik.

Tidak cukup sampai disitu saja, setelah memahami paradigma dan metoda berikutnya adalah berdialog pada bab-bab. Bab berikutnya harus berdialog dengan teks melalui dua hal, pertama teknis penyajian data. Pesan emik disampaikan melalui teknis penyajian data dimana emik dominan jika penulis dalam penyajian data memberi ruang yang besar kepada data emik informan, baik itu disampaikan melalui peneliti apalagi diberi ruang bagi informan untuk bersuara secara langsung pada karya tersebut. Emik peneliti tidak diperhitungkan dalam hal ini, karena selain sulit mendeteksinya, juga emik peneliti sering tidak relevan dengan pesan yang akan disampaikan pada teks karya tersebut.

Kedua, materi yang disampaikan bukan dalam rangka menguji teori. Pesan teks seharusnya lebih bersifat dialogis antara teori dan data yang diperoleh di lapangan. Teori bukanlah menjadi sesuatu yang harus benar atau salah, tetapi teori dan data berdilog sehingga tedapat satu komunikasi yang optimal dimana suara informan mampu menjelaskan teks lebih empirikal. Sementara teori bukan dimaksudkan untuk menguji data sesuai atau tidak sesuai. Jika pesan ini tidak begitu dominan pada karya etnografi tersebut, bisa disebut dominant etik.

Secara lebih teknis bagaimana proses saya melakukan analisis teks karya etnografi, beberapa tahap berikut perlu diketahui pembaca; Pertama , menetapkan buku yang akan dianalisis. Untuk menetapkan buku yang akan dianalisis maka beberapa langkah yang saya lakukan. Yaitu 1) mencari ketokohan penulis buku tersebut yang dikaitkan dengan perkembangan paradigma dalam antropologi. Maka saya memilih Geertz 
sebagai tokoh utama yang bukunya akan saya bahas pada atiketl ini. Alasannya karena Geertz adalah tokoh yang semula sangat kukuh dengan paradigma strukturalis fungsionalisme kemudian dengan gagah berani melahirkan paradigma baru yang sangat berbeda. Sebenarnya saya sudah memilih 4 buku Geertz tetapi karena beberapa pertimbangan sehingga saya memutuskan 3 bukunya saja, yaitu dua buku Geertz berada dibawah payung struktural fungsionalisme yaitu The Religion Of Java dan Paddlers and Princes. Buku pertama dipilih karena karya monumentalnya Geertz, buku kedua dipilih karena ternyata Geertz juga terpengaruh pada paradigma materialisme kebudayaan yang berkembangn tahun 60-an walaupun Geertz sendiri tidak mengakuinya. Saya menduga, seandainya Harris tidak melahirkan paradigma materialisme kebudayaan, maka Geertz akan menjadi tokoh penting pada paradigma ini. Tetapi karena sudah didahului Harris, maka Geertz justeru melahirkan paradigma yang lebih penting yaitu interpretif simbolisme.

Buku Geertz ketiga adalah artikel monumentalnya yang merupakan implementasi dari paradigma interpretifi simbolisme, yaitu Deep Play : Note a Balinese Cockfight. Buku ini sangat penting bagi saya terutama untuk kepentingan menulis artikel ini, sebab buku iini menjadi penanda bagi era kemunculan emik pada karya etnografi. Membaca artikel ini, memberi kesadaran pada kita bahwa memahami masyarakat tidak cukup hanya melalui indikator-indikator dan generalisasi saja tetapi perlu diperdalam karena generalisasi banyak menghilangkan kenyataan yang ada dalam masyarakat.

Dua buku lain yang pilih adalah 2) buku Hildred Geertz yang membahas keluarga jawa, yang sebenarnya bagi saya untuk melihat bagaimana pengaruh struktralisme dalam keluarga Geertz. Hildred ternyata sangat terpengaruh oleh pemikiran Geertz yang menandakan bahwa begitu kuatnya paradigma struktrural fungsionalisme dalam pemikiran Geertz. Ini penting bagi saya bahwa kita tidak mesti dikungkung oleh satu paradigma, bahkan Geertz membuktikannya, dengan bermigrasi dari paradigma struktural fungsionalisme ke paradigma interpretif simbolik yang dibuatnya sendiri. Buku lain adalah 3) karya James C Scott, Senjata Orang-orang Kalah. Buku ini saya pilih atas pertimbangan melihat pengaruh muncul paradigma interpretif pada bidang ilmu lain.

Scott yang bisa dibilang ahli sosiologi politik atau tepatnya ilmuan politik ternyata sangat terpengaruh oleh paradigma interpretif simbolisme khususnya perspektif emik pada penelitian sosial; Kedua, saya harus membaca lima buku tersebut berulang kali sampai bisa memahami bagaimana penulisnya memperlakukan etik dan emik dalam karyanya. Tentu saja bukan hanya pada level teknis pengambilan data tetapi sampai ke paradigma, saya harus mengakui sangat kesulitan ketika memahami buku yang ditulis oleh Scott, karena membaca buku tersebut terkesan sangat etik, tetapi mengapa buku tersebut sangat jauh dari paradigma konflik perspektif Mark. Setelah saya baca berulang-ulang ternyata perlakuan terhadap emiknya yang dominan.;Ketiga, untuk memahami bukubuku tersebut maka saya menggunakaan tiga indikasi, tentu saja indikasi tersebut dibaca dengan menggunakan pendekatan interpretif simbolisme dimana teks dibiarkan otonom lalu diberi hak bagi teks untuk menyampaikan maknanya sendiri. Ketiga indikasi tersebut adalah, paradigma yang lengket pada buku tersebut. Untuk melihat paradigma tersebut cukup membaca standar yang harus dipenuhi setiap karya berdasarkan paradigamnya, jika kesulitan lalu lihat bahan bacaannya maka akan terlihat sumber bacaan dominan yang berkaitan dengan paradigma tertentu. Indikasi kedua, teknik kerja lapangan, apakah kerja lapangan tersebut menggunakan observasi partisipasi yang tanpa panduan secara etik atau sebaliknya. Namun untuk menyederhanakannya, saya melihat berapa lama karja lapangan dilaksanakan apakah dia mempunyai panduan atau tidak. Jika kerja lapangan cukup lama dan tidak mempunyai panduan yang ketat maka kerja lapangan tersebut sudah dipastikan benar-benar emik.

Indikasi ketiga, adalah indikasi penyajian. Bagaimana teknik 
poenyajiannya, saya membagi tiga, teknik, 1) penyajian secara etik dimana etik mengkonstruksi emik, jadi emik dibahas secara etik. Buku Geertz tentang Penjaja dan Raja dan buku Hildred tentang keluarga Jawa merupakan contoh yang baik untuk itu. 2) penulisnya menarasikan emik kedalam teks etnografinya. Suara informan dan fakta lapangan dinarasikan melalui penulisnya, dalam konteks ini saya sebut semi emik, karena perangkat pemikiran penulis dipakai untuk menarasikan emik, karya Geertz tentang sabung ayam di Bali dan karya Scott Senjata Orang-orang Kalah merupakan contoh yang baik untuk dibaca. Sama menamai semi emik karena saya sadar bahwa plot-plot yang dinarasikan tersebut tentu sudah ada campur tangan penulis atas kepentingan teks tersebut. 3) suara informan disampaikan langsung dalam teks-teks etnografi. Jadi data emik muncul secara langsung tanpa perlu melalui narasi penulisnya. Geertz pada bukunya The Religion Of Java melakukan itu, tetapi posisinya sebagai penguat dari etik. Sedangkan karya Ana Tsing Dibawah Bayang-Bayang Ratu Intan, merupakan contoh yang sangat baik untuk ini.

Untuk bisa mengetahui ini, maka langkah selanjutnya adalah medeteksi informasi etik dan emik tersebut pada setiap alinea tersebut. Caranya, tinggal dilihat apakah alinea tersebut etik, emik atau semi emik. Etik jika alinea tersebut ditulis oleh penulisnya dengan berdasarkan panduan teoritis secara tegas. Emik jika alinea tersebut menampilkan secara langsung suara informan dan semi emik jika penulisnya yang menarasi emik informan.

Namun saya mengalami banyak kesulitan dalam menganalis buku tersebut, pertama, proses memahami teks yang ada di ailinea ke tema umum dalam satu bab dan tema buku. Untuk mengatasi ini saya memilih cara deduktif, yaitu memahami pesan tema buku, kemudain tema bab lalu baru masuk ke tema alinea. Setelah itu baru mengetahui bahwa aliniea tersebut mewakili kepentingan etik atau emik. Etik jika aliniea dipakai untuk memperkuat teori, emik jika setiap teks tersebut dipakai untuk memperkuat otonomi emik. Kedua, saya sangat kebingungan membedakan antara emik peneliti dengan etiknya peneliti. Jadi saya tidak bisa membedakannya. Begitu juga mengetahui etiknya informan karena peneliti tidak terlalu terbuka mengungkapkan identitas informan kecuali pada buku Scott Senjata Orang Kalah. Akhirnya saya putuskan tidak akan membahas emik peneliti dan etik informan, saya secara spekulatif memutuskan bahwa diluar emik informan semua adalah etik nya peneliti dan semua dari informan adalah emik.

\section{G. Etik - Emik Perangkat Metodologis \\ ada bagian ini saya akan memaparkan diskripsi hasil analisis
karya etnografi perspektif emik dan} etik berdasarkan tiga hal penting, yaitu paradigma, studi lapangan (field work) dan teknis penyajian (voice) sebagaimana yang dituangkan pada bab sebelumnya. Saya memilih lima buku untuk dianalis secara mendalam. Tiga diantaranya buku karya Clifford Geertz atas pertimbangan ketokohan Clifford Geertz dalam antropologi yang telah berjasa melahirkan paradigma interpretif simbolik. Dua buku diambil semasa Clifford Geertz masih berpegang teguh pada paradigma struktural fungsional, dan satu karya monomentalnya memasuki paradigma interpretif simbolik. Dua buku lain, yaitu karya Hildred Geertz yang merupakan isteri Clifford Geertz yang saya maksud untuk melihat interaksi Clifford Geertz dengan Hildred Geertz dalam karya etnografinya dan satu buku lagi, merupakan karya dari James C Scott.

\section{Analisis Karya Etnografi}

U raian berikut merupakan hasil analisis buku - buku yang dipilih atas prtimbangan perkembangan paradigma dalam antropologi. Uraian ini dibagai menjadi dua bagian, pertama uraian pada masing-masing buku dalam hal ini ada enam buku. Kedua, uraian buku secara keseluruhan tentang perspektif emik dari keseluruhan karya tersebut;

\section{a. Clifford Geertz (1981) Abangan Santri dan Priayi Dalam Masyarakat Jawa, Jakarta Pustaka Jaya \\ Buku ini diterbitkan pertama sekali tahun 1960 oleh The Free Press London dengan judul The Religion of Java, kemudian diterjemahkan kedalam bahasa}


Indonesia oleh Aswab Mahasin dengan judul Abangan Santri dan Priayi Dalam Masyarakat Jawa. Tahun 1981 dicetak oleh Pustaka Jaya.

\section{i. Paradigma}

Buku ini merupakan studi lapangan Geertz di Mujokuto selama setahun. Menurut saya buku ini ditulis, pertama, sebagai implementasi dari tulisannya Religion as Cultural System (agama sebagai inti kebudayaan) terbit tahun 1966, namun tahun 1956 dia juga menulis Religious Belief and Economic Behavior in A Central Javanese Town : Some Preliminary Consideration. Saya berpendapat demikian, karena semua tulisan Geertz tersebut mempunyai hipotesis dasar bahwa agamalah yang menjadi penggerak kelakuan manusia. Tulisan-tulisan Geertz lain baik di Jawa maupun di Maroko memberi kesan sedemikian kuat bahwa dasar utama kelakuan manusia ada agama. Hanya sayangnya saya belum mengetahui kehidupan beragama Geertz, sehingga saya tidak mengasumsikan tampilnya emik Geertz pada hipotesis tersebut.

Kedua, hipotesis Geertz juga dibangun berdasarkan perkembangan politik aliran yang terjadi secara nasional tahun 50-an. Politik aliran yang dimaksud adalah kekuatan politik yang tercermin melalui partai politik, yaitu nasionalis, agama dan komunis. Saya berpendapat demikian, karena dari indikasi dan variable yang ditunjukkan Geertz pada masing-masing variasi agama tersebut menunjukkan kolerasi yang sangat kuat dengan tiga kekuatan politik tersebut. Walaupun tidak terlalu tepat karena abangan yang desa tidak selalu komunis, priayi yang birokrasi tetap ada yang santri, begitu juga santri tidak harus di pasar saja. Melalui politik aliran ini, Geertz ingin menjelaskan struktur sosial di Jawa dipengaruhi oleh sistem kepercayaan yang mencorakan kelakuan yang berbeda pada masing-masing struktur tersebut. Tulisan Geertz tentang The Javanese Kiaji: The Changing Role of a Cultural Broker tahun 1960 sangat jelas menghubungkan politik nasional dengan struktur sosial di kota kecil.

Geertz sendiri mengakui bahwa struktur sosial jawa yang dia bangun tidak selalu bisa berkomunikasi secara baik dengan empirik yang dia jumpai. Secara sadar atau tidak Geertz menampilkan emik seorang NU tradisional berprilaku modernis, seorang wanita desa yang abangan bergaya priayi dan seorang abangan selalu memilih proses santri dalam ritual kematian. Geertz mengakui ini sebagai variasi campuran, di mana masing-masing variasi tidak secara utuh taat kepada sistem nilai yang berlaku pada variasinya. Secara paradigmatik uraian diatas memastikan buku ini dominan etik.

Membaca teks karya tersebut secara langsung dapat menjelaskan bahwa paradigma yang dipakai Geertz pada buku ini adalah paradigma struktural fungsionalisme. Melihat masyarakat berdasarkan struktur dan fungsi dan dikotak-kotakan dalam sistem agama, ekonomi, sosial dan politik diantara kota itu saling mempengaruhi satu sama lain, dan Geertz meletakan agama sebagai sistem inti.

Geertz sendiri mengakui pada bab akhir dari buku bahwa dia memakai paradigma struktural fungsionalisme, melalui piramida yang dia buat pada halaman 482 misalnya. Apalagi disetiap peristiwa dan perayaan yang ditonjolkan oleh Geertz adalah fungsi dari perayaan tersebut. Paradigma struktural fungsionalisme inilah yang membuat Geertz dengan mudahnya menyederhanakan struktur sosial dengan sistem keyakinan sekaligus membuktikan bahwa agama menjadi inti dari kebudayaan. Penyederhanaan merupakan ciri utama paradigma struktural fungsionalisme, yang tentu saja akan sangat berbeda pendapat dengan paradigma materialisme kebudayaan dan interpretif simbolik.

\section{ii. Kerja Lapangan}

Field research, membaca teknik studi lapangannya akan sangat menarik jika kita membandingkan dengan apa yang dilakukan Malinowski (1922) di kepulauan Trobian. Malinowski adalah tokoh antropologi sosial Inggeris yang menerapkan teknik emik dalam penelitiannya. Geertz sendiri juga menerapkan perspektif emik ini dalam penelitiannya, terbukti sebelum ke Mojokuto Geetz mendalami Indonesia selama satu tahun di Belanda, kemudian 
satu tahun pula mendalami bahasa Jawa di Yogyakarta dan setahun lebih berada di Mujokuto untuk proyek penelitian tersebut bersama team besarnya.

Walaupun sama-sama struktural fungsionalisme, Geertz lebih positivis dari Malinowski. Malinowski memposisikan lebih dahulu data emik etik, lalu emik dibawa masuk ke kotak-kotak struktural fungsionalisme. Sedangkan Geertz berlaku sebaliknya, dia buat dulu kotakkotak dan menentukan kotak inti lalu data emik dimasukan ke kotak-kota tersebut sebagaimana saya uraikan pada bagian awal dari pembahasan buku ini. Hanya saja, agak susah membuktikan bahwa dalam etik tersebut terdapat emiknya penulis, atau dalam emik informan terdapat emiknya penulis.

Saya lebih seneng menyebutkan pada bagian ini sebagai kontestasi etik dan emik, bahwa terjadi kontestasi antara etik dan emik pada karya ini. Ini akan sangat terlihat pada bagian penyajian nanti. Geertz ---sangat jelas-- tidak begitu saja mengabaikan data emik disaat dia harus memasukan emik tersebut ke kotak etiknya. Saya mengulangi contoh sebelumnya yaitu seorang NU tradisional berprilaku modernis, seorang wanita desa yang abangan bergaya priayi dan seorang abangan selalu memilih proses santri dalam ritual kematian. Ini bukti kuat yang nantinya mendorong Geertz keluar dari paradigma struktural fugnsionlis ke interpretif simbolisme.

\section{iii. Penyajian dalam Teks}

Voice atau teknik penyampainnya. Pada bagian ini sebenarnya merupakan bagian yang sangat penting untuk melihat karya etnografi dari persfektif etik dan emik. Karya etnografi itu sendiri bisa bicara dengan jelas tentang bagaimana penulisnya memposisikan etik dan emik dalam karya tersebut, meskipun paradigma sangat etik.

Teks-teks yang ada pada setiap alenia dipahami melalui pendekatan interpretif simbolisme, lalu teks tersebut ditabulasi melalui konten analisis secara terbatas. $^{3}$ Tabel analisis konten tersebut

\footnotetext{
${ }^{3}$ Maksud terbatas disini adalah konten analisis hanya dipakai untuk mendeteksi berapa alinea yang emik, semi emik dan etik, tidak sampai
}

dapat membantu dengan mudah memahami perspektif etik dan emik pada karya tersebut, karena dikuantifikasi melalui kemunculannya disetiap bab.

Saya menggunakan tiga indikasi etik atau emik untuk mengungkapkan voice atau bagaimana etik dan emik disajikan pada karya etnografi ini, yaitu 1) penulis sebagai menarasi suara informan, hal ini bermakna emik bertrasformasi menjadi semi emik dalam karya etnografi 2) informan langsung bersuara, ini bermakna emik betul-betul muncul hingga ke karya etnografi dan kita sebut emik dan 3) data emik dikontruksi secara etik. ${ }^{4}$ Karya tersebut benar-benar etik, karena emik sudah dikonstruksi sedemikian rupa sehingga menjadi etik. Ketiganya akan dilihat intensitas munculnya pada judul buku, judul bab, judul sub bab dan isi pada setiap alinea. Dari indikasi ini akan diketahui pada bab mana etik dan emik muncul secara dominan.

Untuk menghindari kerumitan mendiskripsikannya melalui tabel berikut:

membahas situasi lingkungan yang terjasi pada saat penelitian itu dilaksanakan.

${ }^{4}$ Penjelasan secara detail bisa dilihat pada bab sebelumnya bagian Pendekatan dan Metoda Analisis 
Table 2 : Analisis Kontens perespektif etik dan emik

\begin{tabular}{|c|c|c|c|c|}
\hline & Semi Emik* & Emik * & Etik $^{*}$ & \multirow{4}{*}{ Tema pada Bab } \\
\hline Judul Asli & & - & 1 & \\
\hline Judul Bab & 9 & - & 13 & \\
\hline Judul Sub Bab & 49 & - & 67 & \\
\hline \multicolumn{5}{|c|}{ Materi atau isi (pada alinea) } \\
\hline Pendahuluan & - & - & 25 & Lokasi Penelitian \\
\hline Bab 1 & 15 & 4 & - & Ritual Selametan \\
\hline Bab 2 & 35 & 4 & - & Mahluk Halus \\
\hline Bab 3 & 22 & 3 & - & Ritual Pertunangan \\
\hline Bab 4 & 35 & 3 & - & RitualKelahiran \\
\hline Bab 5 & 66 & 11 & - & Khitanan \& Perkawian \\
\hline Bab 6 & 27 & 4 & - & Ritual Kematian \\
\hline Bab 7 & 21 & 2 & - & Hari-hari baik \\
\hline Bab 8 & 72 & 20 & - & Ritual Pengobatan \\
\hline Bab 9 & 2 & 5 & 10 & Gerakan Kejawen \\
\hline Bab 10 & - & 3 & 29 & Konflik santri-abangan \\
\hline Bab 11 & - & 7 & 45 & Sejarah Islam \\
\hline Bab 12 & 1 & 8 & 32 & Konflik aliran dlm Islam \\
\hline Bab 13 & - & 11 & 36 & Organisasi Pesantren \\
\hline Bab 14 & 48 & 15 & 36 & Sistem Pddk Pesantren \\
\hline Bab 15 & 12 & 10 & 15 & Islam dan Negara \\
\hline Bab 16 & 24 & 14 & - & Tata cara ibadah \\
\hline Bab 17 & 73 & 12 & 19 & Gaya hidup priayi \\
\hline Bab 18 & 50 & 15 & 13 & Gaya hidup priayi \\
\hline Bab 19 & 48 & 10 & 2 & Gaya hidup priayi \\
\hline Bab 20 & 61 & 32 & 16 & Mistik priayi \\
\hline Bab 21 & - & 9 & 12 & Sekte mistik \\
\hline Bab 22 & 26 & 12 & 67 & Konflik dan integrasi \\
\hline Tambahan & - & - & 15 & Metoda \\
\hline
\end{tabular}

Sumber : Diolah dari Hasil Kajian Konten

* Semi emik adalah nasari emik disampaikan oleh peneliti, emik adalah informan tampil secara langsung dalam karya etnografi, dan etik, eksplanasi emik yang sudah dikontruksi secara etik (teori), penjelasan ini juga berlaku untuk tabel serupa berikutnya

Dari tabel diatas memunculkan beberapa fakta penting, pertama pada judul asli buku, judul bab dan judul sub bab, etik muncul secara dominan lalu diikuti seringnya muncul semi emik. Indikasi yang benar-benar emik tidak muncul sedikitpun. Saya memahami ini sebagai ciri dari paradigma struktural fungsionalisme yang sangat mementingkan generalisasi. Judul buku, bab dan sub bab merupakan generaslisasi dari isi yang ingin disampaikan. Kedua, pada bab 1 hingga $s$ bab 8 dan 16, yang paling menonjol justeru semi emik dan emik. Mengapa terjadi begini? Jawabannya bersifat spekulatif karena seharusnya tidak terjadi pada etnografi yang berbasis paradigma struktural fungsionalisme. Menurutnya saya fakta ini terjadi karena pada bab ini merupakan pengetahuan baru bagi penelitinya. Oleh sebab itu, peneliti berusaha mengabstraksikan data-data tersebut secara semi emik dan emik, walaupun kemunjulan emik tidak begitu signifikan dibandingkan data semi emik. Untuk menghindari kesalahan abtraksi maka penelitinya membiarkan emik muncul sebagai bentuk dari generalisasi itu sendiri. Ketiga, bab 10 hingga 14, dan bab 21 yang paling dominan muncul adalah etik lalu dilengkapi dengan emik. Jika dipahami lebih mendalam munculnya dominan etik pada bab - bab itu hal ini tampak sangat terkait dengan hipotesis Geertz bahwa agama sebagai inti kebudayaan. Pengetahuan Geertz tentang Islam di Indonesia sudah lebih baik. Hipotesisnya agama sebagai inti kebudayaan tersebut sangat jelas mempengaruhi pada bab tersebut diatas. Sehingga bab ini sangat dominan etik, sementara emik sendiri muncul untuk kepentingan memperkuatan etik. 
Keempat, bab 9, 12, 14 , 15, 17,18,20 dan 22 emik, semi emik dan etik muncul secara bersamaan. Kemunculan ketiga indikasi ini menandakan bahwa Geertz sendiri secara inten mendialogkan antara etik dengan emik secara berulang-ulang. Perangkat etik yang disodorkan Geertz sudah cukup mapan, tetapi tidak cukup untuk berdialog dalam hal menjelaskan perayaan agama, dan etika serta gaya hidup priayi. Keduanya muncul bersamaan karena saling melengkapi. Namun demikian jika dipelajari lebih mendalam tetap saja indikasi etik dan semi emik muncul lebih dominan daripada indikasi emik.

Buku karya Geertz ini bisa disimpulkan lebih dominan etik, mulai dari paradigmanya yang memposisikan harus etik, ini terlihat jelas bahwa data etiknya jauh lebih besar dari data emik dan semi emik. Walaupun field work secara teknisnya emik dan proses pengambilan datanya emik, tetapi paradigmanya masih positivis, yaitu mengambil data atas hitoris yang diajukan. Namun demikian, pada karya ini sangat dinamis berkomunikasi dan kontestasi antara etik dan emik, muncul secara bergantian dalam setiap alinia yang dituangkan pada setiap lembaran buku tersebut.

\section{b. Geertz, Clifford (1992) Penjaja dan Raja, (terjemahan) Jakarta : Yayasan Obor}

Buku ini diterbitkan pertama sekali tahun 1963 oleh Unversity Chicago Press dengan judul Peddlers and Princes. Tahun 1973 buku ini sudah diterjemahkan kedalam bahasa Indonesia oleh Yayasan Obor, kemudian diterbitkan Gramedia. Buku ini termasuk banyak diminanti buktinya sudah dicetak sampai lima kali masing-masing dua edisi di yayasan Obor, dua edisi di gramedia dan sekali terbitan pertamnya. Artikel yang sama juga ditulisnya untuk mendiskripsikan pasar di Maroko, (1978) 'The Bazaar Economy: Information and Search in Peasant Marketing', The American Economic Review, Vol. 68,

\section{i. Paradigma}

Buku ini mendiskripsikan dua kota yaitu Mujokoto dan Tabanan Bali terutama dua pasarnya. Menurut saya Geertz sangat terpengaruh oleh pemikiran Malinowski yang melihat ekonomi tidak berdiri sendiri. Geertz berhasil secara meyakinkan menghubungkan ekonomi dengan sosial dan budaya. Pasar dibentuk oleh struktur sosial dan pasar membentuk struktur sosial pula. Contoh yang konkrit yang ditampilkan adalah keengganan pedagang di pasar meminjam uang ke pemerintah dengan bunga rendah, tetapi tetap meminjam ke pedangan di pasar dengan bunga lebih tinggi karena struktur sosial yang terbangun di pasar tersebut dan keterjaminan barang.

Bazaar (1978, 1992) konsep yang dikembangkan Geertz untuk menjelaskan pasar di Maroko dan Mujokuto. Konsep bazaar tentu saja dimaksudkan Geertz untuk membedakan dengan konsep market (pasar) di Eropah. Jika dipahami lebih dalam maka bazaar yang dimaksud adalah pasar tradisional, disitu dijual bahan kebutuhan pokok berupa sandang, pangan dan perumahan, terutama sekali kebutuhan harian. Jumlah barangnya terbatas dan bisa dengan mudah berpindah-pindah dan hubungan dengan pembelinya tidak terikat.

Geertz (1992) menjelaskan bazaar dengan tiga sudut pandang, yaitu pertama arus barang dan jasa menurut pola tertentu. Arus barang dan jasa yang diperjualbelikan adalah bahan pangan, sandang, dan barang besi kecil-kecilan dan sebagainya yang mudah diangkut dan disimpan, jumlahnya bisa dengan mudah ditambah dan dikurangi sesuai dengan keadaan. Hanya barang-barang seperti tekstil yang beroperasi agak besarbesaran. Jumlah penjualan sangat tinggi, volume sangatlah kecil karena besarnya jumlah transaksi. Barang yang tahan lama cenderung lama berputar-putar di pasar sebelum sampai kepada konsumen sebenarnya. Bahkan sehelai kain untuk sampai ke konsumen bisa berpindah sampai 10 kali. Sumber barang dan arus barang sebagian besar berasal dari daerah dimana pasar itu berada (Mujokuto). Pasar menjalani unsur produksi dan distribusi sebagai satu kesatuan.

Kedua, mekanisme pengatur arus barang dan jasa. Mekanisme pengaturan barang dan jasa dalam bentuk tiga hal yang sangat penting, yaitu 1) sistem harga luncuran. Dimana pedagang memberi 
harga dengan margin keuntungan yang besar lalu terjadi tawar menawar yang meriah sampai kepada suatu margin keuntungan yang pantas. Pada sistem ini, persaingan bukan dengan pedagang lain tetapi antara pedangan dengan pembeli. Pedagang dan pembeli mengandalkan keterampilan tawar menawar sampai mendapat harga yang pantas. Oleh sebab itu, pusat perhatian pedagang sepenuhnya pada transaksi (pertukaran) dengan pembeli agar mendapat keuntungan yang besar. 2) neraca yang kompleks dari hubungan-hubungan kredit yang diselenggarakan dengan hati-hati. Pada pasar itu terdapat hirarki pedagang yaitu pedagang kecil yang berhutang ke pedagang besar, dan pedagang yang besar behutang kepada pedagang yang lebih besar sebagai suatu mekanisme modal. Pedagang lebih suka memperoleh kredit dengan bunga yang besar dari swasta daripada bunga rendah dari pemerintah, hal ini melibatkan posisi hirarki dari pedagang tersebut. Sistem kreditnya ini sebenarnya bisa menjelaskan posisi pertukaran tauke dengan kleinnya, sebagaimaan yang dicontohkan Geertz melalui tulisan Ju-kang T'en yang mengambarkan secara jelas posisi tauke.

3) pembagian resiko yang akan mendatangkan laba yang lebih kecil. Pola ini adalah bagaimana pedagang besar mempelopori pembagian resiko dengan memberi ruang kepada pedagang kecil berjualan dengan modal darinya. Pedagang eceran meminjam uang kontan kepada pedagang yang lebih besar untuk melakukan jual beli yang lain. Uang kontan ini berpfungsi sebagai alat untuk mendapatkan kredit. Atau uang kontan menjadi alat untuk membayar kredit agar kredit tetap mengalir. Pembagian resiko ini bisa memastikan bahwa pedagang besar tidak akan mengalami kerugian walau dengan untung tidak begitu besar.

Ketiga, sistem sosial dan kebudayaan dimana mekanisme tersebut tertanam. Ciri-ciri sistem sosial dan kebudayaan di pasar bazaar adalah 1) posisi "terselib" (interstitial) pada masyarakat jawa umumnya. Ini sebabkan sebagian besar dari pasar tersebut tumbuh bukan karena pertumbuhan setempat melainkan dimasukan dari luar. Tenaga pendorong berkembangnya ekonomi setempat bukanlah disebabkan oleh pedagang setempat dan bukan pula karena pembikinan barang setempat, melainkan pedagang jarak jauh dan pedagang internasional. 2) pembagain kerja yang sangat berkembang. Pembangian ini sebagai konsekwensi belum berkembangnya organisasi gilda apapun di pasar. Tidak ada frima-firma yang mempunyai pegawai, bahkan antara pedagang, dan tukang tidak terdapat persekutuan. Sehinga pasar tersebut muncul secara langsung dari pembagian kerja tadi, dari sistem pekerjaan itu sendiri. Pembagian kerja tersebut dibagi berdasarkan poros jaringan distribusi atau menurut barang yang dijual. 3) pemisahan yang sangat tajam antara ikatan-ikatan sosial yang khas ekonomis dengan yang non ekonomis. Ikatan para pedagang bisa dikatakan sangat spesifik karena ikatan komersial tersebut dipisahkan sama sekali dengan ikatan sosial persahabatan, ketetanggaan, bahkan kekerabatan. Ekonomi terlepas dari hubungan pribadi, penuh perhitungan, dan rasional. Para pedagang tersebut juga berhubungan satu sama lain dengan menggunakan istilah yang sangat teknis yang membebaskana mereka dari ikatan khusus seperti dengan adik, kakak, anak, suami, isteri yang umumnya berdagang sendiri-sendiri di pasar.

Uraian diatas mengindikasikan bahwa Geertz pada karya ini sebenarnya sangat terpengaruh oleh paradigma materialisme kebudayaan ${ }^{5}$. Indikasi ini sangat kuat dilihat dari cara Geertz mendiskripsikan pasar yang sangat numerik dan pengaruh material kebudayaan terhadap prilaku budaya pasar. Tahun yang sama Geertz (1993) juga menerbitkan buku, Agricultural involution: the process of ecological change in Indonesia yang menurut saya sangat dipengaruhi oleh paradigma materialisme kebudayaan. Teks besar buku ini tetap berada dalam kotak struktural fungsionalisme, ini terlihat bagaimana hipotesis Geertz tentang lemahnya organisasi pasar di Mujokuto

\footnotetext{
5 Marvin Harris di awal tahun 1960-an mempelopori paradigma materialisme kebudayaan yang menekankan bahwa kebudayaan terbentuk karena pengaruh material yang ada dilingkungannya.
} 
dan Tabanan sebagai suatu sumber masalah utama pasar di Indoensia dan kemunculan pengusaha Indonesia. Hipotesis ini tentu saja muncul dari konsepsi pasar yang berkembang di Amerika dan Eropah.

Sebagaimana layak paradigma struktrual fungsionalisme dan juga materialisme kebudayaan maka teks ini tentu sangat positivis yang bertujuan untuk mendapatkan generalisasi dari data yang tersedia. Saran-saran yang disampaikan Geertz pada bagian akhir buku ini juga mencerminkan kerapa berfikir struktural fungsionalisme. Geertz memberi saransaran yang sangat antropologis yang dipandangnya mampu membangun pengusaha Indonesia dan sekaligus membangun Indonesia ke depan.

\section{ii. Kerja Lapangan}

Buku ini merupakan hasil kerja lapangan dari dua riset, dua tahun di Mujokuto yang merupakan penelitian sebelumnya yang menghasilkan buku Religion of Java dan setahun di Bali, yang menurutnya juga berkunjung ke Mujokuto. Selain dari informasi ini, tidak tersedia informasi lain yang bisa menjelaskan bagaimana proses kerja lapangan yang dilakukan, baik itu di Mujokuto maupun di Tabanan.

Sepertinya, buku ini hasil dari dua riset tersebut tetapi riset itu sendiri tidak dimaksudkan untuk menulis buku ini. Data yang tersedia pada penelitian sebelumnya tersebut menjadi material bagi penulisan buku ini. Oleh sebab itu, bisa dikatakan bahwa penilitian buku ini dilakukan secara emik dan betul-betul emik. Karena buku ini muncul berada dari skenario peneleitian sebelumnya. Dengan demikian, buku ini betul-betul menguatkan bahwa buku The Religion Java benar-benar positivisme karena data yagn tidak berkiat dengan hipotesis disingkirkan dan bisa menjadi satu buku baru.

\section{iii. Penyajian dalam Teks}

Voice atau teknik penyajian dalam teks buku ini ternyata sangat dominant etik. Oleh sebab itu dari tiga indikasi yang saya pakai untuk melihat teknik penyajiannya, indikasi emik tidak muncul sedikitpun. Bahkan pada bagian diskripsi tentang lokasi penelitian terutama di
Tabanan semuanya dikontruksi oleh penelitinya. Data yang ditampilkan data yagn sudah dikonstruksi oleh penelitinya. Pada buku ini tidak tersedia ruang emik dan semi emik. Semuanya etik, cara penyampaiannya sangat kuat mengidikasikan pada paradigma materialisme, dimana emik hanya proses pencarian data sacara emik setelah itu semuanya harus etik. Emik hanya ada pada proses kerja lapangan, begitu data diperoleh penyajiannya dimunculkan secara etik.

Buku karya Geertz ini juga dapat disimpulkan lebih dominant etik, mulai dari paradigmanya yang memposisinykan harus etik. Hanya saja para proses kerja lapangan data pada buku ini tanpa prosedur pengujian hipotesis melainkan data yang tidak terpakai pada laporan penelitian sebelumnya.. Namun demikian, pada karya ini tidak muncul komunikasi dan kontestasi antara etik dan emik, karena dari awal penulisnya langsung memunculkan dominasi etik.

\section{c. Geertz, Clifford (1992) (tejmahan) Permaian Mendalam : Catatan Tentang Sabung Ayam di Bali dalam Tafsir Kebudayan, Yogyakarta : Kanisius}

Artikel ini diterbitkan tahun 1972 oleh Daedalus: journal of the American Academy of Arts and Sciences, vol 101 no. 1, kemudian menjadi artikel penting dalam bukunya The Interpretation of Cultures, yang terbit tahun 1973. Artikel ini sangat penting bagi karir ilmuan Geertz. Karya ini mengukuhkan paradigma interpretif simbolik dalam antropologi sebagai salah satu paradigma penting dalam kajian antropologi. Basis kerja dari paradigma ini adalah mencari makna dari berbagai simbol yang bertebaran dalam masyarakat dan dilakukan secara mendalam. Artikel ini, menjadi contoh penting untuk melakukan etnografi interpretif simbolisme.

\section{i. Paradigma}

Sebagai titik awal berkembangnya paradigma interpretif simbolik maka artikel ini menjadi poin penting bagi Geertz bagaimana melakukan penelitian yang berbasis paradigma interpretif simbolik tersebut. Jelas sekali pada artikel ini menampilkan paradigma interpretif 
simbolik hadir secara nyata. Mulai dari judul, sub judul dan teknih penyajian sangat terasa perspektif emik hadir disitu. Kuatnya perspektif emik dalam karya ini menjadikan interpretif simbolik sebagai ikon perspektif emik. (Moris, 1999).

Melalui artikel ini, Geertz mendiskripsikan makna dibalik sabung ayam di Bali. Geertz berusaha untuk tidak mengeksplanasi atas peristiwa sabung ayam tersebut. Tetapi Geertz menemukan makna penting sabung ayam sebagai suatu konstruksi sosial masyarakat Bali. Dibalik sabung ayam tersebut, ada suatu bangunan kultur yang besar, tentang status, tentang kepahlawanan, kejantanan, dan etika sosial yang menjadi dasar pembentukan kultur Bali.

Pada artikel ini tampak jelas bagaimana proses Geertz menemukan sabung ayam sebagai sautu simbol. Sabung ayam tidak dibawa oleh peneliti tetapi ditemukan di kerja lapangan. Menurut saya, kesadaran bahwa sabung ayam sebagai simbol muncul ketika bersarnya respon masyarakat terhadap Geertz yang ingin mendengar cerita tentang dirinya yang lari sampai terjatuh karena menghindar dari aparat kepolisian. Lalu bagaimana kehadirannya yang manipulatif dirumah warga sambil minum teh dipandang mampu menyelamatkan uang hasil taruhan untuk bangun sekolah, menyelamat tuan tanah dan kepala desa. Perisitwa yang dialami Geert tersebut menyebar dan ada disetiap kepala di desa yang ditelitinya. Dari situ, Geertz, mengkontruksi sabung ayam dengan pranata sosial yang ada di Bali. Sabung ayam ternyata menurut Geertz bukan sekedar judi, tetapi sudah merupakan simbol ekspresi dari status, otoritas dan lain sebagainya.

\section{ii. Kerja Lapangan}

Interpretif simbolik memandang penting pengumpulan data emik demi kepetingan data itu sendiri ( Saefudin, 2006). Sebagai pendukung utama dari data emik adalah kerja lapangan dengan pendekatan observasi terlibat dengan waktu yang lama. Tujuannya adalah bagaimana data merupakan formulasi dari realitas masyarakat itu sendiri. Geertz dalam bukunya yang lain, (1983) paradigma interpretif simbolik mencoba memahami pemahaman yang bukan pemahaman peneliti. Oleh karena itu posisi etik ketika melakukan kajian lapangan dengan menggunakan paradigma interpretif simbolik ditiadakan. (Saefudin 2006). Ini berarti kerja lapangan untuk menulis karya etnografi ini benarbenar emik.

Ini tergambar dengan sangat jelas, bagaiamana proses awal Geertz dan isterinya terlibat dalam permainan adu ayam tersebut. Data ditutur secara detail dari menit ke menit dan peristiwa dibuat secara berurutan tanpa ada sedikitpun unsur etik. Semuanya ditulis apa adanya. Perbandingan dibuat dalam konteks emik pribadi peneliti, seperti dia membandingkan prilaku polisi Indonesia dengan polisi di Amerika Serikat.

\section{iii. Teknik Penyajian}

Membaca teks dari artikel ini, seperti kita membaca penuturan seseorang tentang peristiwa yang dia lalui. Pada teks ini peneliti bertindak sebagai penutur, semua data emik ditururnya secara runut tanpa campur tangan etik. Konstruksi penulis hanya berada diranah penataan agar data emik tersebut mampu mengungkapkan makna dibalik peristwa tersebut. Konstruksi penulis itu sendiri dibimbing oleh paradigma yang dianut penulis. Artikel ini, mulai dari judul, sub judul pilihan kata-katanya diambil secara emik atau apa yang terjadi.

Melalui analisis konten di ketahui bahwa dari 103 tiga alinie hanya 28 alinie yang etik yang perannya sebagai penjelasan atau pemberi makna, 75 alinia merupakan data emik yang dituturkan oleh peneliti. Penuturan hanya menuturkan apa yang terjadi, jadi tidak dipenguhi oleh etiknya peneliti. Tapi tidak satupun emik tersebut tampil secara langsung, padahal pada buku yang The Religion of Java, emik banyak sekali tampil secara langsung yang fungsinya hanya penguat saja. Sedangkan pada artikel ini, dimana posisi emik sangat dipentingkan dan otonom, justru suara secara emik secara langsung tidak tampil sama sekali.

Jelas sekali, bahwa artikel ini sangat dominan emik. Etik hanya dipakai untuk memberi makna dari emik. Ini berarti se- 
emik apapun karya etnografi tetap etik dan emik sebagai satu metodologis yang tidak bisa dipisahkan. Keduanya saling berkomunikasi walau hanya terbatas dan tidak berkontestasi.

Secara keseluruhan dari karya Geertz ini tampak sekali pergeseran perspektifnya, pergeseran tersebut dipengaruhi oleh pergeseran paradigma yang dianutnya. Geertz pada akhir tahun 1960-an secara meyakinkan tidak lagi berdedikasi pada paradigma struktural fungsionalisme tetapi sudah bermigrasi ke paradigma interpretif simbolik yang dihasilkan karir keilmuannya sendiri. Perobahan ini mempengaruhi secara keseluruhan mulai dari cara berfikir, teknik lapangan dan teknik penulisan.

\section{d. Hildred Geertz, 1985, Keluarga Jawa (terjm), Grafiti Press.}

Hildred Geertz merupakan isteri dari Cliford Geertz dan sekaligus sebagai anggota tim peneliti tentang kebudayaan jawa. Oleh sebab itu istilah-istilah yang dipakai Geertz dalam buku The Religion of Java dan Padler and Princes juga muncul dalam buku ini. Buku ini diterjemahkan ke dalam bahasa Indoenesia tahun 1983 oleh Grafiti Press dan telah mengalami tiga kali cetak. Ini menandakan buku ini diminati banyak orang.

Secara keseluruhan buku ini berisi eksplanasi penulisnya tentang keluarga Jawa di Mujokoto. Penulisnya menelaah secara mendalam 15 keluarga dan 30 keluarga sebagai informan tambahan (tidak begitu jelas maksudnya informan tambahan ini). Hildred dengan cerdik menggunakan fungsi-fungsi institusi rumah tangga sebagai unit analisis utamanya. Melalui unit analisis ini, Hildred bisa menjelaskan banyak hal, meliputi hubungan pertalian dalam keluarga, tradisi mulai dari perkawainan, melahirkan, hubungan antar anak, dewasa, seks dan nilai-nilai kejawen dalam keluarga.

\section{i. Paradigma}

Pada masa penelitian ini dilaksanakan paradigma yang sedang mendapat tempat dalam ilmu sosial adalah struktural fungsionalisme. Sebagaimana C Geertz pada masa itu, Hildred sangat jelas menggunakan paradigma ini dalam karya ini. Hildred dengan jelas memahami keluarga sebagai satu institusi yang terdiri dari struktur -struktur yang menempatinya fungsinya masing-masing. Bab 2 oleh Hildred secara tegas memakai judul yang sangat etik, yaitu "Struktur Sistem Pertalian Keluarga Jawa”. Satu judul yang meletakan pentingnya analisa struktur untuk memahami keluarga jawa.

\section{ii. Kerja Lapangan}

Pada bagian lampiran II Hildred menjelaskan secara terbuka bagaimana kerja lapangan dilaksanakan. Kerangka hipotetisnya sangat kelihatan dengan cara dia membagi informan berdasarkan katagori abangan, santri dan priyai yang mana kompoisi santri 6 , priayi 5 dan abangan 4. dari keterangan metodeloginya, diketahui bahwa kerja lapangan ini dilakukan dengan panduan indikator-indikator yang telah ditetapkan sebelumnya.

Sebagaimana cara kerja paradigma struktural fungsionalisme etik menjadi alat utama untuk mendapatkan emik (Harris,1976). Kerja lapangan yang dilakukan Hildred secara maksimal terutama dalam mencari data berdasarkan kerangka hipotesis yang sudah dibuatnya. Untuk mendapat data yang diinginkan Hidred melakukan kerja emik dengan tinggal lama di masyarakat, tetapi data yang diambil terbatas pada ruang hipotesis yang disediakan. Artinya emik yang didekati secara positivis, sesuai dengan karangka teori yang dibuat.

\section{iii. Teknik Penyajian}

Hidldren secara konsisten menyajikan tulisannya dalam karangka struktural fungsionalisme, teks-teks disajikan secara etik dan emik muncul untuk mendukung kebenaran etik. Walaupun pada kenyataannya Hildred membiarkan emik muncul diluar kemampuannya untuk menjelas banyak hal dalam keluarga yang belum bisa dijelaskan secara etik. Tapi Hidred dengan kukuh memegang kendali etik. Sebagai contoh, Hildred tidak bisa menghidar untuk menampilkan bagaimana perangkat penghormatan pada keluarga jawab bukan bedasarkan umur. Jadi bisa saja orang yang berumur 20 tahun dipanggil kakek oleh yang berumur 40 tahun. Dalam konteks ini ternyata 
struktural fungsionalis gagal berfungsi dalam kasus ini sehingga fungsi struktur keluarga berubah. Maka mau tidak mau emik muncul disini tanpa bisa dikendali. Untuk menunjukkan kuatnya etik dalam buku ini dapat dilihat pada tabel berikut:

Tabel 3 : Analisis Kontens perespektif etik dan emik

\begin{tabular}{|l|c|c|c||c||}
\hline & Semi Emik & Emik & \multicolumn{1}{||}{ Etik } & \multirow{2}{*}{ Tema Bab } \\
\hline \hline Judul Asli & - & - & 1 & \\
\hline Judul Bab & - & - & 3 & \\
\hline Judul Sub Bab & - & - & 12 & \\
\hline \multicolumn{2}{|c|}{ Materi atau isi (pada alinea) Materi atau isi (pada alinea) } \\
\hline Bab 1 & 1 & - & 49 & Lokasi Penelitian \\
\hline Bab 2 & 15 & - & 181 & Struktur Keluarga \\
\hline Bab 3 & 10 & - & 205 & $\begin{array}{c}\text { Fungsi dan } \\
\text { sosialisasi nilai }\end{array}$ \\
\hline Lampiran 2 & & - & 24 & Metoda \\
\hline
\end{tabular}

Sumber : Diolah dari Hasil Kajian Konten

Saya membaca tabel ini dengan dua pendapat, pertama, tabel ini memperkuat posisi paradigma struktural fungsionalisme pada buku ini. Tampak bahwa tidak satu emik muncul dalam buku ini. Hanya 26 alinia saja yang berisi emik yang dituturkan oleh peneliti atau semi emik, sementara terdapat 459 alinia yang benar etik, suatu dominasi etik yang sangat kuat. Kedua, sebagaimana di buku Religion of Java posisi emik disini dimaksudkan untuk mempekuat etik dan alat diskripsi penulis terhadap data pada satu tema pembahasan yang baru bagi penulis. Maka tidak ada pilihan lain selain memunculkan emik yang dituturkan melalui penulisnya. Dua pemahaman ini, kembali memperkuat bahwa etik dan emik bukan suatu konsep yang yang berhadapan.

\section{e. Scott, James, S, 2000, (terjemahan) Senjata Orang-Orang Kalah : Bentuk Perlawanan Sehari-hari Kaum Tani, Jakarta, Yayasan Obor}

Buku ini mengangkat tema antropologi kekuasaan, meliputi tema politik perlawanan kaum lemah di Sedaka Malaysia. Terbit pertama sekali tahun 1985 di Amerika Serikat dan diterjemahkan kedalam bahasa Indonesia tajun 2000. Buku ini menarik sekali untuk memahami bagaimana sebuah perlawanan tanpa bentuk dan tanpa organisasi. Perlawanan tersebut tidak berdiri sendiri tetapi perlawan trsebut mempunyai sejarah panjang mulai dari konflik lokal, nasional dan internasional. Sekali lagi, buku ini membuktikan bahwa kekuasaan ada ditangan siapa saja dan perlawanan bisa dilakukan kapan saja baik saat kuat ataupun lemah.

\section{i. Paradigma}

Membaca buku ini secara mendetail dan berulang-ulang, lalu memperhatikan daftar bacaannya, semakin jelas bahwa paradigma konflik dari Marx sangat kuat tampil mulai dari awal hingga akhir buku ini. Soctt dalam melakukan penelitian dan proses penulisannya tidak meletakan paradigma konflik Marx sebagai kerangka yang harus diikuti di lapangan. Dalam hal ini Scott memperlakukan emik sebagai suatu yang otonom kemudian baru dilihat kecenderung emik tersebut menuju ke mana. Karena Scott seorang ilmuan politik dan banyak menulis pemberontakan petani maka ketika data yagn otonom tersebut dibawa ke paradigma konflik ternyata menemui bentuk yang berbeda. Secara politik tidak ada perlawanan seperti itu. Maka munculnya konsep resistensi sebagai bentuk perlawanan yang lebih kultural.

Meskipun masih bersifat spekulatif, menurut saya karya ini sangat dipengaruhi paradigma interpretif simbolik dari Geertz walau hanya terbatas teknik memahami data emik. Nyatanya pada analisis pengaruh Marx sangat kuat, bahkan dilhat dari penyajian angka-angka dan analisis lingkungan perangkap structural fungsionalisme masih sangat dominan. Ini dapat dimaklumi karena Scott bukanlah antropolog tetapi ilmuan politik yang menggunkan pendekatan antropologi dalam melakukan kajian lapanganya. Saya melihat ketika Scott menuangkan laporan 
penelitiannya posisinya sebagai ilmuan politik muncul begitu kuat dan antropologi kembali berada diwilayah kerja lapangan.

Harus diakui bahwa pengaruh antropologi juga cukup besar dalam karya ini, perlawanan tanpa bentuk, melalui sindiran, fitnah dan penamaan alias hanya bisa diperolehnya melalui antropologi. Atas kesadaran itu akhirnya dia menterjemahkan perlawanan dalam bentuk yang lebih kultural. Kesadaran ini, juga dipengaruhi oleh arus besar ilmu sosial ditahun 1980-an yang sedang memperbincangkan postmoderisme karena kekecewaan pada struktural fungsionalisme. Resistensi bisa menjadi solusi terhadap kenyataan ilmu sosial yang ada pada masa itu.

\section{ii. Kerja Lapangan}

Paradigma interpetif simbolisme yang berada di ranah postmoderisme sangat menngutamakan data emik. Scott yang ilmuan politik tersebut semula agak kewalahan menjalani proses kerja lapangan etnografi. Scott berada di Sedaka selama 14 bulan, Scott sangat meyadari kebenaran yang diserakan penduduk kampong kepadanya. Maka tidak dapat disangkal lagi bahwa Scott melakukan kerja lapangan tidak sematamata untuk mendapatkan data emik saja. Tetapi Scott betul-betul meletakan emik sebagai suatu yang amat penting. Dengan demikian, maka kerja lapangan yang dilakukan Scott benar kerja emik yang bukan terbatas pengambilan data emik saja, tetapi memaknai data emik tersebut secara otonom.

\section{iii. Teknik Penyajian}

Saya mendapati Scott menyajikan karyanya agar perspektif emik tetap muncul dalam setiap teks yang dia tampilkan dengan cara, yaitu pertama, memberi ruang emik untuk tampil melalui narasi yang di sampaikan. Ditengah teks etik yang tampil, tiba-tiba muncul teks emik yang fungsinya bukan sebagai penjelas, atau penguat data etik. Teks itu muncul sebagai dasar pemaknaannya, seperti ketika membahas tentang bentuk amal, dimana kenduri disebut sebagai bagian dari amal, tiba-tiba muncul teks "seperti dikatakan Mansur, orang miskin ditarik ke kenduri-kenduri oleh bau wangi masakan daging" menurut Scott, teks ini secara simbolis menjelaskan fungsi kenduri sebagai bentuk amal

Kedua, ternyata pada teknik penyajian laporan ternyata sangat dominan etik. Tetapi etik yang ditampil oleh scott merupakan kontruksi dari emik. Bukan etik datang lalu mengkonstruksi emik, tetapi justeru sebaliknya emik yang mengkonstruksi etik sehingga etik yang disampaikan merupakan penyuaran dari emik. Jadi kerangka teorinya tidak muncul duluan, tetapi mengikuti data emik. Scott menarasikan apa yang dijumpai sepanjang penelitian dan bagaimana dia memaknai hari-hari yang dia lalui tersebut, sambil bersentuhan dengan etik. Dari situ makna resistensi muncul sebagai simbolisme sosial pada masyarakat Sedaka, sebagai terjemahan dari konsepsi perlawanan

Untuk mepertegas pendapat tersebut berikut saya tampilakn analis konten dari tiga indikasi yang saya pakai untuk melihat perspektif dominant pada karya tersebut; 
Table 4 : Analisis Kontens perespektif etik dan emik

\begin{tabular}{|c|c|c|c|c|}
\hline & $\begin{array}{l}\text { Semi } \\
\text { Emik }\end{array}$ & Emik & Etik & \multirow{4}{*}{ Tema Bab } \\
\hline Judul Asli & & - & 1 & \\
\hline Judul Bab & & - & 8 & \\
\hline $\begin{array}{l}\text { Judul Sub } \\
\text { Bab }\end{array}$ & & 2 & 48 & \\
\hline \multicolumn{5}{|c|}{ Materi atau isi (pada setiap alinea) } \\
\hline Bab 1 & 78 & - & 23 & Gejala resistensi \\
\hline Bab 2 & - & - & 75 & Sejarah perlawanan petani \\
\hline Bab 3 & - & - & 120 & Ekologi dan kebijakan \\
\hline Bab 4 & 12 & - & 168 & Diskripsi Sedaka \\
\hline Bab 5 & 36 & - & 160 & Kesadaran resistensi \\
\hline Bab 6 & 62 & - & 189 & Pola Resistensi \\
\hline Bab 7 & 33 & - & 221 & Stategi resistensi \\
\hline Bab 8 & - & - & 170 & Kesadaran kelas \\
\hline
\end{tabular}

Sumber : Diolah dari Hasil Kajian Konten

- Bagian pendahuluan tidak dianalisis karena membahas pengamalan penelitiannya, cara memnaca buku dan ucapan terima kasih ke berbagai pihak.

Sepintas dari tabel tersebut, buku ini disajikan dengan sangat dominan etik. Memang kenyataannya alinea-aline yang disusun berdasarkan tema besar disetiap bab bersifat etik. Hanya kembali lagi, bahwa Scott menampilkan etik tersebut sebagai kontruksi emik. Logika sederhananya, jika data tersebut sangat etik maka Scott tidak akan menemukan konsep resistensi pada penelitian ini. Scott telah memaknai emik secara otonom, lalu dia mencari penjelasan-penjelasan etik untuk memperkuat emik tersebut. Jadi kerangka besarnya emik tetapi dijelaskan secara etik.

\section{H. Emik Makin Menguat}

ari lima buku yang dianalisis agak mendalam diatas, tampak kecenderungan emik semakin menguat. Penguatan ini disebabkan hadirnya paradigma interpretif simbolik dan postmoderime. Walaupun sebenarnya lima buku ini bukan mewakili karya etnografi yang lain, tetapi dari kelimanya kelihatan bahwa semakin ke tahuan 2000 semakin emik muncul. Berikut dapat dilihat pada tabel dibawah ini:

Tabel 5. Perbandingan 5 buku etnografi perspektif emik dan etik

\begin{tabular}{|c|c|c|c|c|c|}
\hline NO & Judul Buku \& thn terbit & Paradigma & Kerja Lapangan & $\begin{array}{l}\text { Teknik } \\
\text { Penyajian }\end{array}$ & Keterangan \\
\hline 1 & $\begin{array}{l}\text { Geertz, } 1960 \\
\text { The Religion Of Java }\end{array}$ & $\begin{array}{l}\text { Struktural } \\
\text { Fungsionalisme }\end{array}$ & $\begin{array}{l}\text { Emik dikonstruksi } \\
\text { oleh etik }\end{array}$ & Etik dan emik & $\begin{array}{l}\text { Etik dan emik } \\
\text { berkonstetasi } \\
\text { tampik pada } \\
\text { karya etnografi }\end{array}$ \\
\hline 2 & $\begin{array}{l}\text { Geertz, } 1960 \\
\text { Peddlers and Princes }\end{array}$ & $\begin{array}{l}\text { Struktual } \\
\text { Fungsionalisme }\end{array}$ & $\begin{array}{l}\text { Emik dikonstruksi } \\
\text { oleh etik }\end{array}$ & Etik & $\begin{array}{l}\text { Dominan Etik, } \\
\text { emik hanya } \\
\text { metode }\end{array}$ \\
\hline 3 & $\begin{array}{l}\text { Hildred, } \\
\text { The } \\
\text { Fanimily }\end{array}$ & $\begin{array}{l}\text { Struktual } \\
\text { Fungsionalisme }\end{array}$ & $\begin{array}{l}\text { Emik dikonstruksi } \\
\text { oleh etik }\end{array}$ & Etik & $\begin{array}{l}\text { Hanya tahun } \\
\text { penerbitan } \\
\text { Indonesia saja } \\
\text { Etik dan emik } \\
\text { berkonstetasi }\end{array}$ \\
\hline 4 & $\begin{array}{l}\text { Geertz, } 1973 \\
\text { Deep Play : Note on } \\
\text { the Balinese Cockfight }\end{array}$ & $\begin{array}{l}\text { Interpretif } \\
\text { Simbolisme }\end{array}$ & Emik & Emik dan etik & $\begin{array}{l}\text { Emik } \\
\text { mengkontruksi } \\
\text { etik }\end{array}$ \\
\hline 6 & $\begin{array}{l}\text { James C Scott, } 1985 \\
\text { Weapons of the Weak: } \\
\text { Everyday Forms of } \\
\text { Peasant resistance }\end{array}$ & $\begin{array}{l}\text { Konflik marx } \\
\text { dipengatuhi oleh } \\
\text { Interpretif } \\
\text { Simbolisme } \\
\end{array}$ & Emik & Emik dan etik & $\begin{array}{l}\text { Emik } \\
\text { mengkontruksi } \\
\text { etik }\end{array}$ \\
\hline
\end{tabular}

Sumber : Diolah dari Hasil Kajian Konten 
Tabel diatas menyampaikan pesan bahwa pertama, etik dan emik sesuatu yang bukan untuk dipisahkan keduanya akan selalu ada dalam karya etnografi dan salaing melengkapi. Bahkan pada karya yang positivispun emik tetap muncul sebagai penguata data etik. Karya etnografi lain seperti, Maliwoski (1922) Argonouts of Western Pacific, RadcliffeBrown (1922) The Andaman Inslanders. Oscar Lewis (1959) Five Families, Mexican case Studies in The Culture of Proverty. Margaret Mead (1928) Coming of age in Samoa. Mauss (1965) The Gift : From and Function of Echange in archaic Societies dan buku-buku lainnya.

Kedua, sejak terbitnya buku the interpretation of culture tahun 1973 oleh Geertz, kecenderungan emik lebih dominant dan posisi emik mengantikan posisi etik. Kalau sebelumnya etik yang konstruksi emik dan sekarang yang terjadi adalah emik yang mengkonstruksti etik, etik sebagai penguat emik. Tetapi keduanya tetap muncul dan penting pada setiap karya emik. Khusus Geertz sangat menonjol perubahan etik ke emik karena Geertz merupakan tokoh penting paradigma interpretasi simbolisme. Karyakarya serupa dapat dibaca misalnya pada karya, Heffner (1993) Geger tengger : Perubahan Sosial dan Perkelahaian Politik. Geertz (2000) Negara Teater : Kerajaan-Kerajaan di Bali Abad Kesembilan Belas. Murray (1995) Pedagang Jalanan dan Pelacur Jakarta, Abu-lughod (1986) Veiled Sentiments : Honor and Poetry in a Baduin Scociety dan buku-buku lain yang mempunyai gendre yang sama.

\section{Kesimpulan}

raian-uraian pada artikel ini membawa saya pada beberapa kesimpulan penting, yakni:

1. Memahami karya etnografi melalui perspektif emik bukanlaha pekerjaan yang sederhana, tetapi memerlukan suatu proses yang detail dan teliti. Metode untuk memahami perspektif emik pada karya etnografi dengan memahami paradigma yang menyertai karya tersebut, metoda kerja lapangan, dan teknik penyajian materi dari buku tersebut. Untuk menganalisis perspektif etik dan emik tersebut alat analisis yang bisa dipakai adalah pendekatan interpretif simbolisme dan analisis konten untuk kwantifikasi isi yang disampaikan pada setiap aline.

2. Karya etnografi yang dominan etik bukan berarti mengabaikan emik, emik hadir pada metoda kerja lapangan, dan penyajian isi yang posisi emiknya sebagai penguat dari etik. Begitu juga sebalik, karya yang dominan emik menampilkan data melalui semi emik dan etik yang kedudukan etik tersebut memperkuat emik.

3. Mengetahui emik peneliti dalam karya etnografi akan menghadapi banyak kesulitan karena hambatan pengetahuan tentang peneliti dan kultur dimana peneliti berasal. Sedangn etik informan juga sulit untuk dideteksi dalam karya etnografi karena identitas informan jarang sampaikan secara terbuka dan peneliti juga jarang menyampaikan verivikasi data dari informan apakah merupakan gejalan umum dalam komunitasnya atau justeru hanya gagasan ideal yang diinginkan informan.

4. Etik dan emik merupakan konsep yang sejajar pada setiap karya etnografi, oleh sebab itu tidak mungkin suatu karya etnografi mengabaikan etik atau emik. Seemik apapun karya etnografi pasti memerlukan etik untuk memperkuat emik, begitu juga seetik apapun karya etnografi pasti melibatkan emik, meskipun hanya terbatas metoda pengambilan data saja. Pada kenyataannya etik dan emik saling berkontestasi pada setiap karya etnografi.

5. Posisi etik dan emik pada karya etnografi sangat ditentukan oleh paradigma yang menyertainya. Pada paradigma struktural fungsionalisme etik cenderung dominan, tetapi pada paradigma interpretif simbolisme cenderung dominant emik. Ini disebabkan masing-masing paradigma memperlakukan data emik secara 
berbeda. Pada struktural fungsionalisme emik masih sangat terbatas pada startegi penelitian atau mendapatkan data, sementara paradigma interpretif simbolisme memberi ruang yang sangat otonom kepada emik, sehingga emik bukan saja strategi penelitian tetapi sebagai bagian penting dari paradigma. Kecenderungan pada akhir abad ke 20, emik semakin berkembang pada penelitian antropologi dan etnografi, hal ini disebabkan pengaruh dari paradigma interpretif simbolisme dan posmoderisme. Bahkan pengaruh tersebut juga masuk ke ranah politik emipirik sebagaimana yang dilakukan Scott.

6. Karya-karya etnografi Geertz sebelum tahun 70-an sangat kuat etik, ini terbukti Geertz mempengaruhi secara kuat pula cara berfikir Hildred dalam bukunya Keluarga Jawa. Namun Geertz yang pendekar struktural fungsional tersebut bukanlah seorang yang mendewakan satu paradigma, terbukti dengan keterbukaan pemikirannya Geertz melahirkan paradigma interpretif simbolisnya yang kemudian merubah cara padangnya dengan menjadi emik yang dominan pada setiap karya etnografinya.

7. Bagi saya artikel ini tentu sangat berguna karena akan sangat membantu saya dalam studi lapangan dan penulisan desertasi saya nantinya. Saya sadar sebagai orang pernah kuliah di sosiologi tentu saya sangat kuat dengan paradigma struktural fungsional yang sangat positivisme yang selalu berbicara dengan indikator dan pencapaian hasil. Bermigrasi ke pemikiran antropologi tidaklah mudah, dengan memproduksi artikel ini akan membantu saya untuk memahami proses penelitian untuk desertasi saya.

\section{Daftar Pustaka}

Abu-lughod (1986) Veiled Sentiments : Honor and Poetry in a Baduin Scociety. Barkeley C : Universcity of California Press.

Ahimsa-Putra, Heddy Shri, 2007 (ed 2) Patron \& Klien di Sulawesi selatan, Sebuah Kajian Fungsional-Struktural" Yogya Karta ; Kepel Press

Arifin \& Junaiyah (208) Sintakasis, Jakarta : Grasindo Media.

Eklefina Pattinama (2006) "Isu Emik dan Etik dalam Penelitian Antroplogi" Tugas akhir Mata Kuliah Seminar Antropologi Penelitian, Program Pasca sarjana Departement Antropologi Fisip UI.

Endang P Gularso (2007) "Isu Emik dan Etik dalam Penelitian Antroplogi" Tugas akhir Mata Kuliah Seminar Antropologi Penelitian, Program Pasca sarjana Departement Antropologi Fisip UI.

Feleppa, Robert (1986) Emics, Etics, and Social Objectivity Current Anthropology, Vol. 27, No. 3 (Jun., 1986), pp. 243-255

Fabian, Johanes, 2001, Anthropology with an Attitude : Critical Essay California, Standford University Press

Gurnal Myrdal. Objectivity in social Research, 1988 (Terjm.) LP3ES Jakarta Cet.I

Clifford Geertz (1981) Abangan Santri dan Priayi Dalam Masyarakat Jawa, Jakarta Pustaka Jaya

- (1992) Penjaja dan Raja, (terjemahan) Jakarta : Yayasan Obor

(1992) (tejmahan) Permaian Mendalam : Catatan Tentang Sabung Ayam di Bali dalam Tafsir Kebudayan, Yogyakarta : Kanisius

(1960) The Javanese Kijaji: The Changing Role of a Cultural Broker Comparative Studies in Society and History, Vol. 2, No. 2 (Jan., 1960), pp. 228249 
(1978) The Bazaar Economy: Information and Search in Peasant Marketing , The American Economic Review, Vol. 68, No. 2, Papers and Proceedings of the Ninetieth Annual Meeting of the American Economic Association (May, 1978), pp. 28-32

--2000 (di terjemahan oleh Hartono Hardikusumo) Negara Teater Kerajanaankerajaan Bali abad kesembilangbelas, Yogya karta : Adipura

--1983, cet ke 2,ditjm Aswab Mahasin, Abangan, Santri, Priayi dalam Masyarakat Jawa, Jakata: Pustaka jaya

--1995 (di terjemahan Landung Simatupang) After The Fact; Dua Negeri, Empat Dasawarsa, satu Antropolog, Yogya karta : LKISS

(1963) Agricultural involution: the process of ecological change in Indonesia. Berkeley/Ca./USA 1963: University of California Press,

Guba, Egon G.,\& Yvonna S. Lincoln (2005)"Paradigmatic Controversies, Contradictions, and Emerging Confluences," dalam Norman K. Denzin \& Yvonna S.Lincoln, eds, The Sage Handbook of Qualitative Research (third edition). Thousand Oaks,

Hildred Geertz, 1985, Keluarga Jawa (terjm), Grafiti Press.

Harris, M (1968) The Rise of Anthropology Theory : A History of Theories of Culture. Crowell, New York,

Holstein, James A \& Gubrium Jaber F (2005) "Interpertive Practice and Social Action," dalam Norman K. Denzin \&Yvonna S.Lincoln, eds. The Sage Handbook of Qualitative Research (third edition). Thousand Oaks, London, New Delhi: Sage Publications.

Headland, Thomas N, at al (1990) Etic and Emic The Insider/Outsider Debate, California : Sage Publication.

Harris, Marvin, 1976, "History ans significance of the Etic/Emic Distinction", Jurnal Annual Rieview of Anthropology, Vol 5

Heffner Robert. W (1993) Geger tengger : Perubahan Sosial dan Perkelahaian Politik. Yogyakarta : LKIS

Hefner, Rpbert W, (2000) Budaya Pasar, Masyarakat dan Moralitas dalam Kapitalisme Asia Baru (Terjemahan) Jakrata : LP3ES

Hopkins, Nicholas S. dkk (1977) Brokers and Symbols in American Urban Life Anthropological Quarterly, Vol. 50, No. 2 (Apr., 1977), pp. 65-75

Jennifer Lee 1998, Cultural brokers: Race-based hiring in inner-city neighborhoods, The American Behavioral Scientist; Apr 1998; 41, 7; ABI/INFORM Global pg. 927

Lewis, Oscar (1959) Five Families, Mexican case Studies in The Culture of Proverty. New York: Basic Books Inc

Jewell, Christopher J. (2007) Agents of the welfare state: how caseworkers respond to need in theUnited States, Germany, and Sweden. New York : PALGRAVE MACMILLAN

Lukens-Bull, Ronald.2005, A peaceful jihad : negotiating identity and modernity in Muslim Javal New York : PALGRAVE MACMILLAN

Malinowski, B. 1922 "Argonauts of the Western Pacific" . London: Rouledge.

Malinowski, B (1921) The Primitive Economics of the Trobriand Islanders: The Economic Journal, Vol. 31, No. 121 (Mar., 1921), pp. 1-16

Malinowski, B (1920) Kula; the Circulating Exchange of Valuables in the Archipelagoes of Eastern New Guinea. Man, Vol. 20 (Jul., 1920), pp. 97-105

Marcus, E Goerge, 1998, Ethnography throught thick \& Thin USA, Princeton Universcity Press

Michael W. Morris, Kwok Leung, Daniel Ames, Brian Lickel, Views from inside and outside: Integrating Emic and Etic Insights about Culture and Justice Judgment, The Academy of Management Review, Vol. 24, No. 4 (Oct., 1999), pp. 781-796

Murray, Alison J (1995) Pedagang Jalanan dan Pelacur Jakarta, Jakarta : LP3ES

Mead,Margaret (1928) Coming of age in Samoa. New York : Morrow

Mauss, Marcel (1965) The Gift : From and Function of Echange in archaic Societies . London : Cohen \& Werst 
Nancy Lee Peluso, 2006, Penerjemah Landung Simatupang Hutan Kaya Rakyat Melarat; Penguasaan Sumberdaya dan Perlawanan di Jawa, Konphalindo, Jakarta

Ong, Aiwa. 1987. Spirits of Resistance and Capitalist Discipline. Albany: SUNY Press

Radcliffe-Brown, A.R. (1922) The Andaman Inslanders. New York : Free Press

Roberta D Bear \& Marta Bustilo (1993) Susto and Mal de Ojo among Florida Farmworkers: Emic and Etic Perspectives, Medical Anthropology Quarterly, New Series, Vol. 7, No. 1 (Mar., 1993), pp. 90-100

Sherwood G. Lingenfelter,(1977) Emic Structure and Decision-Making in Yap 'Emic Structure and Decision-Making in Yap, Ethnology, Vol. 16, No. 4 (Oct., 1977), pp. 331-352

Schwandt, A Thomas (1998), "Constructivist, Interpretive Approaches to Human Inqury?" dalam Denzin \& Lincoln (1998) The Landscape of Qualitative Resarch. Theories and Issues ( editor) London, Sage Publications.

Saidi, Acep Iwan, 2008, "Hermeneutika, Sebuah Cara Untuk Memahami Teks" Jurnal Sosioteknologi Edisi 13 Tahun 7, April 2008

Saifuddin, Ahmad Fedyani, 2005, Antropologi Kotemporer ; Suatu PEngantar Kritis Mengenai Paradigma, Jakarta, Prenada Media.

Scott, James, S, 2000, (terjemahan) Senjata Orang-Orang Kalah : Bentuk Perlawanan Sehari-hari Kaum Tani, Jakarta, Yayasan Obor

Tsing,Anna Lowenhaupt 1998 Penerjemah Achmad Fedyani Saifudin, Dibawah BayangBayang Ratu Intan; Proses Marjinalisasi Masyarakat Terasing, Yayasan Obor Jakarta.

Thompson, Charles T. and. Huies, Marilyn J (1968) Peasant and Bazaar Marketing Systems as Distinct Types Anthropological Quarterly, Vol. 41, No. 4 (Oct., 1968), pp. 218-227 